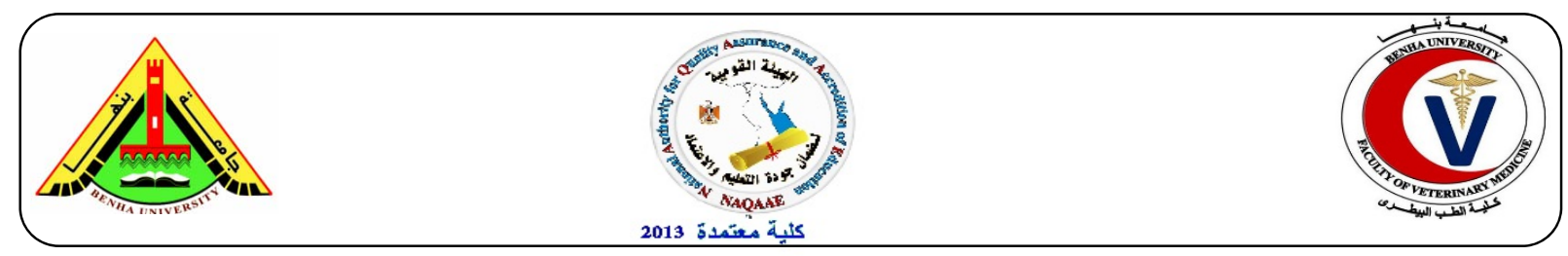

\title{
Bacteriological and molecular studies on toxigenic Staphylococcus aureus in milk and some milk products
}

\author{
Ashraf A. Abd El Tawab ${ }^{1}$, Ahmed M. Ammar², Fatma I. El-Hofy' ${ }^{1}$ Hoda A. Aideia ${ }^{3}$, Eman A. \\ Hammad $^{4}$ \\ ${ }^{1}$ Bacteriology, Immunology and Mycology Dept., Fac. Vet. Med. Benha Univ. ${ }^{2}$ Microbiology Dept., Fac. Vet. Med. \\ Zagazig Univ. ${ }^{3}$ Animal Health Research Institute Dokki, Giza. ${ }^{4}$ General Authority for Vet. Services.
}

\section{A B S T R A C T}

A total of 200 random samples of milk and milk products represented by kareish cheese, yoghurt and icecream (50 for each) were examined microbiologically for the presence of Staphylococcus aureus, its enterotoxigencity and its antibiotic sensitivity. Staphylococcus aureus was isolated from $8(16 \%)$ milk samples, $15(30 \%)$ kareish cheese, 4 (8\%) yoghurt and 11 (22\%) ice-cream samples. All S. aureus isolates exhibited clumping factor using kits for reliable latex agglutination test. The susceptibility of the isolates was determined for 12 antimicrobial drugs using disc diffusion assay. The majority of strains were susceptible to ofloxacin and ampicillin + sulbactam $(100 \%)$, vancomycin and tetracycline $(94.7 \%)$, norfloxacin and sulphamethoxazole + trimethoprim (89.5\%), chloramphenicol (73.3\%) but they were resistant to oxacillin and metronidazole (100\%). Amplification of coagulase gene (coa) using uniplex PCR, staphylococcal enterotoxin genes (sea, seb, sec, sed and see) and methicillin-resistant S. aureus (mecA) gene using multiplex PCR revealed that, 11/11(100\%) of the examined samples were positive for both coa and mecA genes. While, sea produced by $5(45.45 \%)$ strains, sec and sed produced by $4(36.36 \%)$ strains and seb and see were not produced by any strains.

Key words: milk, S. aureus, enterotoxigencity, antibiotic sensitivity, PCR.

(http://www.bvmj.bu.edu.eg)

(BVMJ-31(2): 202-209, 2016)

\section{INTRODUCTION}

Milk serves as an optimum medium for propagation of various pathogenic and spoilage microorganisms (Gatti et al., 2013). Staphylococcal intoxication is considered the second or the third most common food intoxication of microbiological origin (Atanassova et al., 2001). Coagulase positive $S$. aureus is the causative agent of two thirds of food-borne disease outbreaks (Busani et al., 2005). Staphylococcal food poisoning (SFP) is one of the most prevalent causes of gastroenteritis worldwide. Symptoms of SFP have a rapid onset (2 to 6 hours) of abdominal cramps, nausea, and vomiting, sometimes followed by diarrhoea. Patients become symptomatic within 2-4 hours after ingestion of thermostable staphylococcal enterotoxins (SEs) of an approximate dose of 0.1 to $1.0 \mathrm{mg} / \mathrm{kg}$ of body weight (Stewart et al., 2005). There are serologically several distinct enterotoxins that $S$. aureus produced including staphylococcal enterotoxins (SEA to SEE, SEG to SEI, SER to SET) with demonstrated emetic activity (Argudín et al., 2010). Antimicrobial resistance is also of an important public health concern worldwide. Methicillin resistant S. aureus (MRSA) strains resistant to quinolones or multi-resistant to other antibiotics have been emerging, leaving a limited choice for their control (Mee-Marquet et al., 2004; Nejma et al., 2006). PCR assay for detection of genes for $S$. aureus was developed and proved to be specific, sensitive, and rapid method (Omoe et al., 2002; Zschock et al., 2005). As the level of contamination of both milk and its products with different food-borne pathogens constitutes serious problems for consumers, so, the purpose of this study was the evaluation of bacteriological patterns of Staphylococcus aureus as one of the food poisoning micro-organisms in milk and milk products. 


\section{MATERIAL AND METHODS}

\subsection{Samples collections:}

A total of 200 random samples of milk and milk products including yoghurt, kareish cheese and icecream (50 of each) were collected from different large and small dairy plants, street vendors and dairy house in El-Sharkia and Giza Governorates.

\subsection{Bacteriological examination:}

\subsubsection{Preparation of serial dilutions (APHA,} 1992):

\subsubsection{Isolation and identification of staphylococcus aureus:}

Isolation on Baird-Parker medium, Blood agar medium and Milk Salt agar medium was performed according to (APHA, "American Public Health Association" 1992), morphological identification by Gram stain (Cruickshank et al., 1975), biochemical tests (Arora, 2003; Quinn et al., 2002) and serologically by latex agglutination test Dry Spot kit (Staphytect plus) (Oxoid,1990).

\subsubsection{In-Vitro anti-microbial sensitivity method (Finegold and Martin, 1982):}

Using agar diffusion method.

\subsection{Molecular biology technique (PCR):}

\subsubsection{Uniplex PCR:}

For detection of staphylococcal Coagulase (coa) gene using specific oligonucleotide primers sequences for these genes with the length of amplified products at $850 \mathrm{bp}$ according to Goh et al. (1992).

\subsubsection{Multiplex PCR:}

For detection of $S$. aureus enterotoxins genes (sea seb, sec, sed and see) and the methicillinresistant (mecA) genes of $S$. aureus using specific oligonucleotide primers sequences with the length of amplified products for enterotoxins at (102 bp for sea), (164 bp for seb), (451 bp for sec), (278 bp for sed) and (209 bp for see). While, the length of amplified products for methicillin-resistant (mecA) genes at different base pairs $(613,398,280,776$, 493, 200, 881 and $325 \mathrm{bps)}$ according to Mehrotra et al. (2000).

\section{RESULTS}

The bacteriological examination of milk and milk products (kareish cheese, yoghurt and icecream) samples was shown in (Table, 1). The results revealed that $S$. aureus was isolated from 38 $(19 \%)$ of the examined samples represented as, 8
(16\%) milk samples (1 from large scale dairy plants, 1 from small scale dairy plants, 3 from farmer houses and 3 from street vendors), 15/50 $(30 \%)$ kareish cheese samples (1 from large scale dairy plants, 2 from small scale dairy plants, 7 from farmers houses and 5 from street vendors), 4 (8\%) yoghurt samples ( 0 from large scale dairy plants, 0 from small scale dairy plants, 2 from farmers houses and 2 from street vendors) and11 (22\%) ice-cream samples ( 0 from large scale dairy plants, 2 from small scale dairy plants, 3 from farmers houses and 6 from street vendors). The results of in-vitro sensitivity test for the isolated S. aureus indicated the isolated strains were susceptible to ofloxacin and ampicillin + sulbactam $(100 \%)$, vancomycin and tetracycline $(94.7 \%)$, norfloxacin and sulphamethoxazole + trimethoprim $(89.5 \%)$, chloramphenicol (73.3\%) (Table, 2). On the other hand, moderate sensitivity was observed to cephalothin and clindamycin with percentages of $57.9 \%$ and $42.1 \%$, respectively. Moreover, the majority were resistant to oxacillin and metronidazole $(100 \%)$. Confirmation of 11 randomly selected $S$. aureus isolates from milk and milk products using molecular PCR (Table, 3) showed that, coa genes produced by all of the examined $11(100 \%)$ samples (Photo, 1) using uniplex PCR, mecA genes produced by all of the examined 11(100\%) samples (Photo, 2) by multiplex PCR. Multiplex PCR also used for detection of staphylococcal enterotoxin genes (sea, seb, sec, sed and see) and showed that, sea genes produced by $5 / 11$ isolates $(45.45 \%)$, sec and sed produced by $4 / 11$ isolates $(36.36 \%)$. While, seb and see genes did not produced by any isolate (Photo, 3).

\section{DISCUSSION}

The examined samples of milk and milk products (kareish cheese, yoghurt and ice-cream) have been showed S. aureus in $38(19 \%)$ of milk and milk products samples Table (1). Staphylococcus aureus was isolated from $8(16 \%)$ milk samples. Nearly similar findings were postulated by Alnakip (2009); Aman and Ahmed (1996); El-Bessary (2006); El-Jakee et al. (2008); Jakeen et al. (2010); Nassar (2013) who isolated $S$. aureus from $15 \%, 16.66 \%, 17.5 \%, 16 \%$ from buffalo's milk and $22.7 \%$ from cow milk, $16.7 \%$, $19.13 \%$ and $16 \%$, respectively. On the other hand, higher incidence was reported by El-Gendy (2015); Hammad (2004); Mohammed (2002); Ralls et al. (2008); Tondo et al. (2000); Wafy (2006) who isolated S. aureus from $90.4 \%, 64 \%, 80 \%, 60 \%$, 
Table 1. Prevalence of $S$. aureus in milk and milk products $(\mathrm{n}=50)$ :

\begin{tabular}{|c|c|c|c|c|c|c|c|c|c|c|c|}
\hline \multirow{3}{*}{$\begin{array}{l}\text { Type of } \\
\text { samples }\end{array}$} & \multirow{3}{*}{$\begin{array}{c}\text { No. of } \\
\text { samples }\end{array}$} & \multicolumn{4}{|c|}{ Dairy plants } & \multirow{2}{*}{\multicolumn{2}{|c|}{$\begin{array}{c}\text { Farmers } \\
\text { houses }\end{array}$}} & \multirow{2}{*}{\multicolumn{2}{|c|}{ Street vendors }} & \multirow{2}{*}{\multicolumn{2}{|c|}{ Total }} \\
\hline & & \multicolumn{2}{|c|}{ Large scale } & \multicolumn{2}{|c|}{ Small scale } & & & & & & \\
\hline & & No./10 & $\%^{*}$ & No./10 & $\%^{*}$ & No./15 & $\%^{*}$ & No./15 & $\%^{*}$ & $\begin{array}{c}\text { No./ } \\
50\end{array}$ & $\%^{* *}$ \\
\hline Milk & 50 & 1 & 10 & 1 & 10 & 3 & 20 & 3 & 20 & 8 & 16 \\
\hline Kareish cheese & 50 & 1 & 10 & 2 & 20 & 7 & 46.7 & 5 & 33.33 & 15 & 30 \\
\hline Yoghurt & 50 & - & - & - & - & 2 & 13.33 & 2 & 13.33 & 4 & 8 \\
\hline Ice-cream & 50 & - & - & 2 & 20 & 3 & 20 & 6 & 40 & 11 & 22 \\
\hline Total & 200 & 2 & 5 & 5 & 12.5 & 15 & 25 & 16 & 26.7 & 38 & 19 \\
\hline
\end{tabular}

*percentage in relation to No. of each examined samples. ** percentage in relation to total No. of each 50 examined samples.

Table 2. In-Vitro antimicrobial sensitivity test for isolated S. aureus (CLSI, 2014):

\begin{tabular}{|c|c|c|c|c|c|c|}
\hline \multirow[b]{2}{*}{ Antimicrobial agent } & \multicolumn{2}{|l|}{ Sensitive } & \multicolumn{2}{|l|}{ Intermediate } & \multicolumn{2}{|l|}{ Resistant } \\
\hline & $\begin{array}{c}\text { No. of } \\
\text { S. aureus isolates }\end{array}$ & $\%{ }^{*}$ & $\begin{array}{c}\text { No. of } \\
\text { S. aureus isolates }\end{array}$ & $\%^{*}$ & $\begin{array}{c}\text { No. of } \\
\text { S. aureus isolates }\end{array}$ & $\%^{*}$ \\
\hline Ofloxacin & 38 & 100 & - & - & - & - \\
\hline $\begin{array}{l}\text { Ampicillin+ } \\
\text { Sulbactam }\end{array}$ & 38 & 100 & - & - & - & - \\
\hline Vancomycin & 36 & 94.7 & - & - & 2 & 5.3 \\
\hline Tetracycline & 36 & 94.7 & 2 & 5.3 & - & - \\
\hline Norfloxacin & 34 & 89.5 & - & - & 4 & 10.5 \\
\hline $\begin{array}{l}\text { Sulphamethoxazole- } \\
\text { Trimethoprim }\end{array}$ & 34 & 89.5 & 4 & 10.5 & - & - \\
\hline Chloramphenicol & 28 & 73.7 & 6 & 15.8 & 4 & 10.5 \\
\hline Clindamycin & 18 & 47.4 & 16 & 42.1 & 4 & 10.5 \\
\hline $\begin{array}{l}\text { Amoxicillin+ } \\
\text { Clavulinic acid }\end{array}$ & 14 & 36.8 & 8 & 21.1 & 16 & 42.1 \\
\hline Cephalothin & 6 & 15.8 & 22 & 57.9 & 10 & 26.3 \\
\hline Metronidazole & - & - & - & - & 38 & 100 \\
\hline Oxacillin & - & - & - & - & 38 & 100 \\
\hline
\end{tabular}

*Percentage in relation to total number of isolated S. aureus

Table 3. Incidence of coagulase positive, methicillin resistant S. aureus and enterotoxins in randomly selected 11 examined samples of milk and milk products by PCR:

\begin{tabular}{ccc}
\hline $\begin{array}{c}\text { Examined } \\
\text { S. aureus for }\end{array}$ & $\begin{array}{c}\text { No. of } \\
\text { +ve samples }\end{array}$ & $\%^{*}$ \\
\hline Coagulase positive & 11 & $100 \%$ \\
Methicillin resistant & 11 & $100 \%$ \\
Enterotoxins A & 5 & $45.45 \%$ \\
Enterotoxins B & 0 & 0 \\
Enterotoxins C & 4 & $36.36 \%$ \\
Enterotoxins D & 4 & $36.36 \%$ \\
Enterotoxins E & 0 & 0 \\
\hline
\end{tabular}


*Percentage in relation to total number of selected S. aureus isolates

Photos 1, 2 and 3. Agarose gel electrophoresis patterns showing: 1. Uniplex PCR for the S. aureus. 2. Multiplex PCR for methicillin. coagulase (coa) gene, resistant S. aureus (mecA) gene

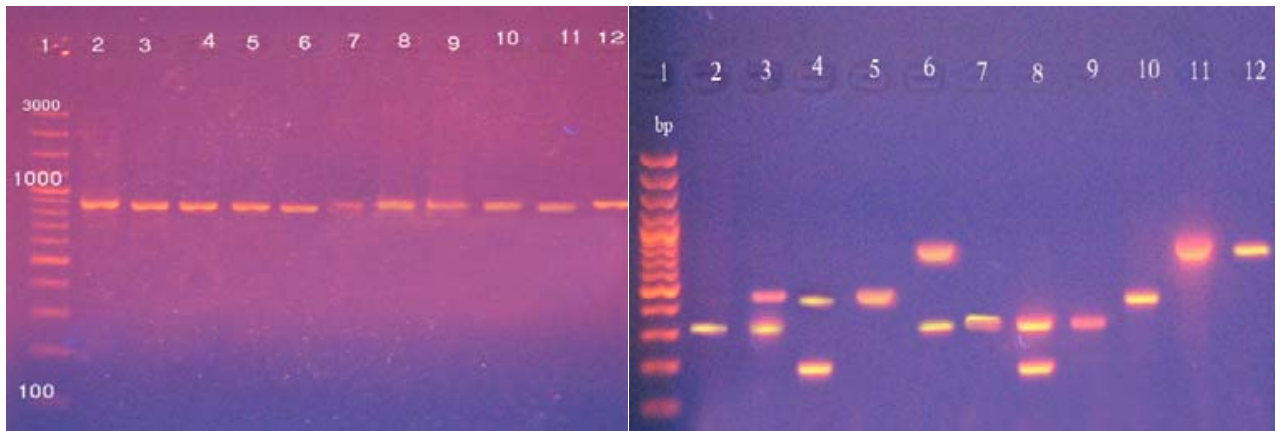

Lanes 1: DNA molecular size marker (100-bp ladder). Lane 2-12: positive sample for coagulase gene and methicillin resistant gene

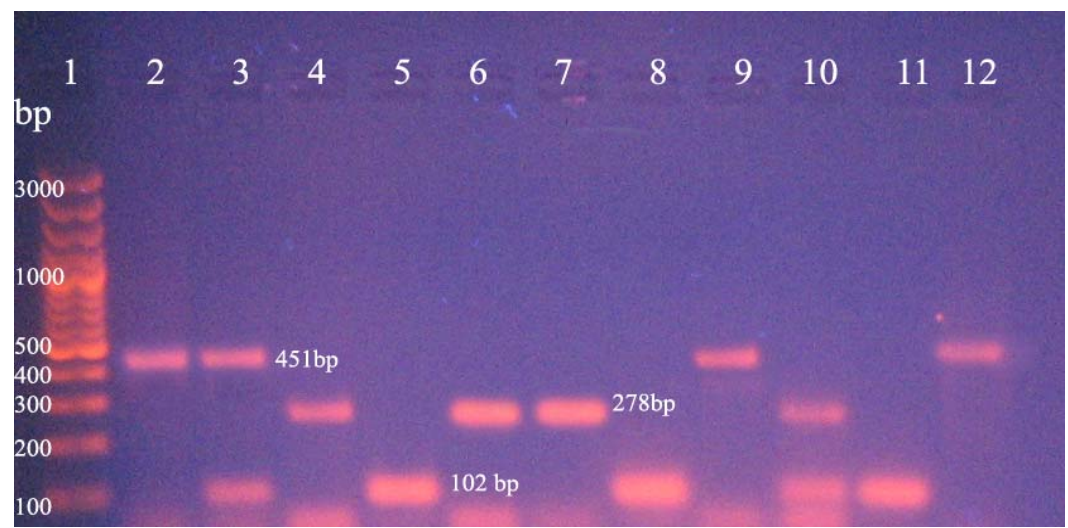

Multiplex PCR amplification products for the S. aureus enterotoxin genes. Lane 1: DNA molecular size marker (100-bp ladder). Lanes 3, 5, 8, 10 and 11: positive samples sea gene at $102 \mathrm{bp.}$ Lanes 2, 3, 9 and 12: positive samples sec gene at $451 \mathrm{bp}$. Lanes 4, 6, 7 and 10: positive samples sed gene at $278 \mathrm{bp}$

$70.4 \%$ and $80 \%$, respectively, but relatively lower incidence was achieved by Amer et al. (2007); Demo et al. (1999); Kivaria et al. (2006); Sudershan and Ashwani (1996) who isolated S. aureus from $12.96 \%, 14.5 \%, 6.3 \%$ and $13 \%$, respectively. Moreover, S. aureus was isolated from 15/50 (30\%) kareish cheese samples. Nearly similar finding to that postulated by Abo-Donia et al. (1975); Ahmed et al. (1988); El-Shater (2010); Hassan (2003) who isolated S. aureus from 33.3\%, $27.5 \%, 30 \%$ and $28 \%$, respectively. On the other hand, higher incidence was reported by Awida (2009); (1999); Hassan (2008); Kolta (2011); Said and Fahmy (1991) who isolated S. aureus from $78 \%, 42.5 \%, 72 \%, 50 \%$ and $70 \%$, respectively, but lower incidence was reported by Ahmed Ahmed et al. (2004); Awad Allah (2004); El-Bessary (2006) who isolated S. aureus from $10 \%$ and $11.25 \%$ in Kafr El-Shaikh and Gharbia Governorates, 12\% and $5 \%$, respectively. S. aureus was isolated from $4 / 50(8 \%)$ of the examined yoghurt. Nearly similar finding to that postulated by El-Biaa (2011); ElShinawy (1987) who isolated S. aureus from 10\% and $12 \%$, respectively. On the other hand, higher incidence was reported by Abdel-Fatah (2007) who isolated S. aureus in $64.44 \%$ of samples. S. aureus could not be detected in industrial processing yoghurt samples; this is in agreement with $\mathrm{Al}$ Tahriri (2005). S. aureus was isolated from 11/50 $(22 \%)$ ice-cream samples. Nearly similar finding to that postulated by Abdel-Fatah (2010); Kamal (2009); Masud (1989) who isolated S. aureus from $26 \%, 22.9 \%$ and $20 \%$, respectively. On the other hand, higher incidence was reported by AbdelHaleem (1995); Abo-Risha (1998); Allam (1999); Hammad (2004); Hassan (2003); Patr et al. (2007) who isolated S. aureus from $84.72 \%, 50 \%, 76 \%$, $56.67 \%, 55 \%$ and $44 \%$, respectively, but lower incidence was reported by Amuramjimi et al. (2008); Kock et al. (1998); Kruy et al. (2001); Little and Louvois (1999); Manzanera-Pelegrin et al. (1995) who isolated S. aureus from $2.7 \%, 4.3 \%$ 
$, 0.5 \%, 12.2$ and $4.4 \%$, respectively. Moreover, Caglayanlar et al. (2009); Korel et al. (2002); Maiereni et al. (1993); Sagdic et al. (2002) could not detect $S$. aureus in any one of the examined icecream samples. Moreover, the results of antibiotic sensitivity tests for the isolated S. aureus Table (2) showed that, S. aureus isolates were highly sensitive to ofloxacin and ampicillin + sulbactam $(100 \%)$, vancomycin and tetracycline $(94.7 \%)$, norfloxacin and sulphamethoxazole + trimethoprim (89.5\%), chloramphenicol $(73.3 \%)$ and they were the most proper antibiotics with the highest efficiency against isolated S.aureus. Meanwhile, they were resistant to oxacillin and metronidazole $(100 \%)$. Nearly similar results of norfloxacin were recorded by Ahmed (2015); Khalil (2014). Nearly similar results of vancomycin were recorded by Nassar (2013) at which the sensitivity to vancomycin was $100 \%$. The sensitivity to ofloxacin (65\%) is also recorded by Ikeagwn et al. (2008). The sensitivity to sulphamethoxazole + trimethoprim $(95 \%)$ is also recorded by Nassar (2013). The sensitivity to chloramphenicol is also recorded by Centorbi et al. (1992); Rossetti (1993) at which it was detected in $94 \%$ and $100 \%$, respectively, also Bobu et al. (2007) mentioned that chloramphenicol was the most effective antibiotics. There is no resistance was detected for ampicillin + sulbactam as recorded by Gentilini et al. (2000). The sensitivity to tetracycline is also recorded by Ahmed (2015); Dutta and Rangnekar (2008); Edward et al. (2009) at which it was detected in $100 \%, 70 \%$ and $85.7 \%$, respectively. Compound oxacillin used to detect MRSA strains and it is also named ORSA (Oxacillin resistant S. aureus). This study explained that all examined $S$. aureus strains were resistant to oxacillin, this result come in agreement to that reported by Khalil (2014) and dis-agree to those reported by Gentilini et al. (2000); Rossetti (1993) who showed that $100 \%$ of the examined strains are susceptible to oxacillin. Our PCR results Table (3) revealed that, uniplex PCR results for coa gene showed that $11 / 11(100 \%)$ of the examined isolates were positive for coa gene. Detection of coagulase gene by PCR was discussed by several authors as by Malahat et al. (2009) at which 21\% of the samples were positive for coagulase gene and Shalaby (2012) reported that, out of the $75 \%$ of 12 S. aureus isolates were positive for coagulase gene. Our multiplex PCR results for enterotoxin genes were so interesting as, sea produced by $5 / 11$ (45.45\%) samples, sec and sed produced by $4 / 11(36.36 \%)$ samples, seb and see not produced by any strains, some of the isolates may carried more than one toxin gene. Detection of staphylococcal enterotoxins by multiplex PCR was discussed by several authors as by Adwan et al. (2005) who reported that, out of the 100 S. aureus isolates (milk sheep origin $=52$, milk cows origin= 48) tested for SE-genes by PCR method, 37\% were positive. None of these isolates carried more than one toxin gene. The majority of these positive toxin gene isolates $20(54.1 \%)$ were seb positive and (Shalaby, 2012) at which the multiplex PCR test revealed that enterotoxin A found in $58.3 \%$ of $S$. aureus isolates, both enterotoxins $\mathrm{B}$ and $\mathrm{C}$ was found in $66.7 \%$ of the isolates and enterotoxin $\mathrm{D}$ was the predominant one found in $75 \%$ of the isolates. The results of multiplex PCR for methicillin resistant $S$. aureus showed that $11 / 11(100 \%)$ of the examined isolates were carrying mecA gene (MRSA). Methicillin resistant S. aureus by multiplex PCR was also detected by several authors as by Bakeet and Darwish (2014); Mulders et al. (2010); Nemati et al. (2008); Oke and Adewale (2013).

The obtained results allow concluding that milk and its products were highly contaminated with high number of $S$. aureus which may lead to undesirable changes that render them unfit for human consumption and indicate unpersonal hygiene and unsanitary conditions during processing and handling. Also, Antimicrobial resistance are widely spread among isolated strains and has been reported to negatively affect the treatment of its associated infections in human and animals.

\section{REFERENCES}

Abdel-Fatah, E.N. 2007. Sanitary studies on fermented milk marketed at Zagazig Markets.M.V.Sc. , Zag. Univ. Egypt.

Abdel-Fatah, E.N. 2010. Role of small and large scale producers in transmission of food poisoning organisms through consumption of ice- cream.Ph.D. Thesis, Zag. Univ., Egypt.

Abdel-Haleem, A.A. 1995. Microbiological evaluation and sanitary improvement of icecream.Ph. D. Thesis, Assiut Univ. Egypt.

Abo-Donia, S.H., Sirry, I., Abdel-Rahman, S.M., 1975. Chemical and microbiologial studies on kareish cheese. . Alex. J. Agric. Res. 23, 243-247.

Abo-Risha, N.E. 1998. Occurrence of some food poisoning microorganisms in some dairy products. M.V.Sc. Thesis, Kafr El-Sheikh Univ., Egypt.

Adwan, G., Bassam, A.S., Kamal, A., 2005. Enterotoxigenic Staphylococcus aureus in 
raw milk in the North of Palestine. . Turk. J. Biol. 29, 229-232.

Ahmed, A.H., Moustafa, M.k., Saad, N.M., Ahmed, S.H., 1988. Occurance of staphylococci in milk and some dairy products. . Assiut Vet. Med. J. 19, 85-89.

Ahmed, H.F., Aman, I.M., Mohamed, A.M., 2004. Bacteriological quality of kareish cheese and atrial to control Staphylococcus aureus in cheese. . Alex. J. Vet. 21, 514-523.

Ahmed, W.A. 2015. Studies on antimicrobial activity of some plat extract against Staphylococcus aureus and Candida albicans with mastitic relevance. Ph.D. Thesis Benha Univ., Egypt.

Al-Tahriri, R., 2005. A comparison on microbial conditions between traditional dairy products sold in Karak and same products produced by modern dairies. . Pakist. J. of nutr. 4, 345-348.

Allam, H.A. 1999. Microbiological studies on milk and some milk products. Ph.D. Thesis., Benha Univ., Egypt.

Alnakip, M.E. 2009. Prevalence of Gram positive bacteria in milk and some dairy products.M.V.Sc. Thesis., Zagazig Univ., Egypt.

Aman, I.M., Ahmed, H.F., 1996. Incidence and survival of some food-borne pathogens in milk and cheese. . Egyptian. Vet. Med. Association 57, 151.

Amer, I.H., Abdel-Aal, S.F., Awad, E.I., 2007. Prevalence of bacterial content and food borne organisms in raw cow's milk. . Alex. J. Vet. Science 26, 153-164.

Amuramjimi, C., Geethu, S., Dhanashree, B., 2008. Bacteriological analysis of ice-cream from Mangalore. South India. Indian J. Med. Res. 127, 91-92.

APHA, "American Public Health Association" 1992. Compendium of methods for the microbiological examination of food, 3rd ed, Washington, D.C., USA.

Argudín, M.A., Mendoza, M.C., Rodicio, M.R., 2010. Food poisoning and Staphylococcus aureus enterotoxins Toxins 2, 1751-1773

Arora, D.R., 2003. Text Book of Microbiology. 2nd Edition (Cultural characteristics of Staphylococcus spp (202-2013), Aeromonas, Plesiomonas (381- 388) Satish Kumar Jain for CBS publishers.

Atanassova, V., Meindi, A., Ring, C., 2001. Prevalence of Staph. aureus and staphylococcal enterotoxins in raw pork and uncooked smoked ham, a comparison of classical culturing detection and RPLAPCR Int. J. Food Microbiol. 68, 105-113.
Awad Allah, M.A. 2004. Studies on proteolytic bacteria in milk and cheese in Zagazig marketsM. V. Sc. Thesis, Zag. Univ., Egypt.

Awida, R.M. 2009. Some studies on S. aureus in milk and some milk products sold in Assiut city with special reference to antibiotic resistant Staphylococcus aureusPh. D. Thesis, Assiut Univ., Egypt.

Bakeet, A.A., Darwish, S.F., 2014. Phenotypic and genotypic detection of methicillin resistant Staphylococcus aureus (MRSA) in broiler chickens. Assiut Vet. Med. J. 60, 142-150.

Bobu, Y.H., Sudhaker, B., Srinivas, C.S., Khan, M.A., 2007. Studies on incidence and vitro sensitivity of isolates to antimicrobial from subclinical mastitis in Jersey cows. Animal heath Centre. . Kurnool. Andhrapradesh, India. Livestock. Adviser 8, 47-49.

Busani, L., Cigliano, A., Tailoli, E., 2005. Prevalence of Salmonella enterrica and Listeria monocytogens contamination in food of animal origin in Italy. . J. food prot. 68, 1729-1733.

Caglayanlar, G.E., Buket Kunduhogul, B., Coksoyler, N., 2009. Comparison of microbiological quality of packed and unpacked ice-cream sold in Bursa, Turkey Journal of Arts and Sciences Sayi 12, 93102.

Centorbi, O.N., Cuadrado, A.M.A., Alcaraz, L.E., Laciar, A.L., Milan, M., 1992. Prevalence of $\mathrm{S}$. aureus isolated from subclinical bovine mastitis in the dairies of San Luis city. Revista Argentina de Microbiol. 24, 73-80.

Cruickshank, R., Duguid, J.P., Marmoin, B.P., Swain, $\quad$ R.H., $1975 . \quad$ Medical microbiology.The practice of medical microbiology page, 12th ed, Churchill, Edinburgh.

Demo, M., Quinones, J., Martin, V., 1999. Dichotomous keys for identifying Staphylococcus isolated from bovine milk. Latinoa. Microbiol. 41, 53-57.

Dutta, S., Rangnekar, A., 2008. Subclinical mastitis in Jersey herd Indian Vet. J. 78, 161162.

Edward, M., Henryka, L., Anna, K., Sebastian, S., Michal, K., 2009. Atypical Staphylococcus aureus as aetiological agent of mastitis in cows Bull Vet Inst Pulawy 53, 383-387.

El-Bessary, M.M. 2006. Sanitary status of milk and some milk products marketed in suburbs of Assiut GovernoratePh.D., Assiut Univ., Egypt.

El-Biaa, N.I. 2011. Evaluation of hygienic quality of large scale manufactured yoghurt M.V.Sc. Thesis, Zag. Univ., Egypt. 
El-Gendy, A.M. 2015. Bacteriological and molecular studies on staphylococcus species isolated from raw milkM.V.Sc. Thesis, Benha Univ., Egypt.

El-Jakee, J., Ata-Nagwa, S., Bakry, M., Zouelfakar-Sahar, A., Elgabry, E., Gad ElSaid, W.A., 2008. Characteristics of Staphylococcus aureus strains isolated from human and animal sources. American Eurasian J. Agri. Environ. Sci. 4, 221-229.

El-Shater, N.S. 2010. Evaluation of immunological and bacteriological patterns of some food poisoning micro-organisms (Staphylococcus aureus and Clostridium perfringens)Ph.D. Thesis, Zagazig University.

El-Shinawy, S.H. 1987. Microbiological studies on fermented milksPh.D. Thesis, Zag. Univ., Egypt.

Finegold, S., Martin, V., 1982. Bailey's and Scott's. Diagnostic Microbiology 6th ed. Mosby Company, St. Louis, Toronto, London.

Gatti, M., Bottari, B., Lazzi, C., Neviani, E., Mucchetti, G., 2013. Invited review: Microbial evaluation in raw milk, long ripened cheese produced using undefined natural whey starters J. Dairy Sci. 97, 573591.

Gentilini, E., Denamiel, G., Liorente, P., Godaly, S., Rebuelto, M., DeGregorio, O., 2000. Antimicrobial susceptibility S. aureus isolated from bovine mastitis in Argentina J. Dairy Sci. 83, 1224-1227.

Goh, S., Byrne, S.K., Zhang, J.L., Chow, A.W., 1992. Molecular typing of Staphylococcus aureus on the basis of coagulase gene polymorphisms. J. Clin. Microbiol. 30, 1642-1645.

Halawa, M.A., Moawad, A.A., 1999. Bacteriiological quality of street-vended white soft cheese Alex. J. Vet. Sci. 15, 855864.

Hammad, A.M. 2004. Microbiological studies on raw milk and some dairy productsM.V.Sc. Thesis, Minufiya Univ., Egypt.

Hassan, G.M. 2003. Quality assessment of some dairy products at cosumer level

M.V.Sc., Cairo Univ., Egypt.

Hassan, W.S. 2008. Microbiological evaluation of some white soft cheese locally manufactured and sold in Assiut cityM.V.Sc. Thesis, Assiut Univ., Egypt.

Ikeagwn, I.J., Amadi, E.S., Iroha, I.R., 2008. Antibiotic sensitivity pattern of Staphylococcus aureus in Abakaliki, Nigeria Pak. J. Med. Sci. 24, 231-235.
Jakeen, k.A., Emad, R.Z., Randa, S.F., 2010. Properties of enterotoxigenic S. aureus isolated from mastitic cattle and buffaloes in Egypt. J. Am. Sci., 6, 170-178.

Kamal, R.M. 2009. Sanitary status of some locally and imported dairy productsPh.D. Thesis, Zag. Univ., Egypt.

Khalil, A.O. 2014. Studies on Staphylococcus aureus and Aeromonas hdrophila associated with a sever outbreak infection in farms rabbitsPh. D. Thesis, Benha Univ., Egypt.

Kivaria, F.M., Noordhuizen, J.P., Kapaga, A.M., 2006. Evaluation of hygienic quality and associated public health hazards of raw milk marketed by small holder dairy producers in the Dar es Salam region, Tanzania. . Trop. Anim. Health Protec. 38, 185-194.

Kock, C., Akan, M., Yardimci, H., 1998. Bacteriological quality of ice-cream marketed in Ankara. Veterinary-FakultesiDergisi-Ankara Univ. 45, 113-134.

Kolta, M.N. 2011. Characterization of Staphylococcus aureus superantigens in milk and some dairy productsPh.D. Thesis, Assiut Univ., Egypt.

Korel, F., Omeroglu, S., Tan, G., Odabaso, A.Z., 2002. The evaluation of chemical and microbiological quality of ice-cream sold in retail markets in Manisa. Turkey. Annual Meeting and food Exo-Anaheim, California.

Kruy, S.L., Soares, J.L., Ping, S., Sainte-Marie, F.F., 2001. Microbiological quality of " ice cream.Sorbet " sold on the streets of Phnom Penh; April 1996- April 1997. Bulletin de la societede pathogenic exotique 94 411-421.

Little, C.L., Louvois, J., 1999. Microbiological Quality of soft ice-cream from fixed premises and mobile vendors. Int. J. Environ. Health Res. 9, 223-232.

Maiereni, M., Civilini, M., Domenis, C., Manzano, M., Di-Prima, R., cami, G., 1993. Microbiological quality of Artisanl icecream. Zentralblatt fur Hygiene und Umvelt Medizin Biological. Abst. 194, 553-570.

Manzanera-Pelegrin, C., Marin-Mesegure, D., Paredes-Garcia, P., Pelegrin, C.M., Mesegure, D.M., Gracia, P.P., 1995. Quality control of ice-cream. Health area III of Mucria region Alimentaria 33, 119-121.

Masud, T., 1989. Microbiological quality and public health significance of ice-cream J. Pak. Med. Assoc. 39, 102-104

Mee-Marquet, N.V., Blanchard, M., Domelier, A.S., Quentin, R., 2004. Virulence and antibiotic susceptibility of Staphylococcus aureus strains isolated from various origins. 
Survey Study Group of the Relais. . Hygie'ne du Centre. Pathol. Biol. 52 579-583.

Mehrotra, M., Wang, G., Johnson, W.M., 2000. Multiplex PCR for detection of genes for Staphylococcus aureus enterotoxins, exfoliative toxins, toxic shock syndrome toxin 1 and methicillin resistance. J. of Clin. Microbiol. 38, 1032-1035.

Mohammed, A.M. 2002. Quality investigation into beef frankfurter produced in Egypt. M.v.sc. Thesis Cairo Univ.

Mulders, M.N., Haenen, A.P., Geenen, P.L., Vesseur, P.C., Poldervaart, E.S., , Bosch, T., Huijsdens, X.W., Hengeveld, P.D., DamDeisz, W.D., Graat, E.A., 2010. Prevalence of livestock-associated MRSA in broiler flocks and risk factors for slaughter house personnel in the Netherlands Epidemiol. Infect. 138, 743-755.

Nassar, M.K. 2013. Phenotypic and genotypic characterization of enterotoxic S. aureus isolated from different sources with reference to antimicrobial resistance M.V.Sc. Thesis, Zagazig Univ., Egypt.

Nejma, M.B., Mastouri, M., Frih, S., Sakly, N., Salem, Y.B., Nour, M., 2006. Molecular characterization of methicillin- resistant Staphylococcus aureus isolated in Tunisia. Diagn. Microbiol. Infect. Dis. 55 21-26.

Nemati, M., Hermans, K., Lippinska, U., Denis, O., Deplano, A., Struelens, M., Devriese, L.A., Pasmans, F., Haesebbrouck, F., 2008. Antimicrobial resistance of old and recent Staphylococcus aureus isolated from poultry: first detection of livestockassociated methicillin resistant strain ST398 Antimicrob. Agents Chemother 52, 38173819.

Oke, A.J., Adewale, A.O., 2013. Incidence of methicillin resistant Staphylococcus aureus (MRSA) in a small poultry in south west, Nigeria. IOSR Journal of Agriculture and Veterinary Science (IOSR-JAVS) 5, 53-55.

Omoe, K., Ishikawa, M., Shimoda, Y., Hu, D.L., Ueda, S., Shinagawa, K., 2002. Detection of seg, seh, and sei genes in Staphylococcus aureus isolates and determination of the enterotoxin productivities of $\mathrm{S}$. aureus isolates Harboring seg, seh, or sei genes. J. Clin Microbiol. 40.

Patr, B., Ztepe, G., Ihak, I., Bozkurt, P., 2007. Microbiological quality of ice-cream marketed in Elzag Veteriner Bilimleri Dergisi.
Quinn, P.J., Markey, B.K., Carter, M.E., Donnelly, W.J., Leonard, F.C., Maguire, D., 2002. Veterinary microbiology and microbial disease 2nd ed. Blackwell Science.

Ralls, V.L., Vieira, F.P., Ralls, R., Vieitis, R.L., Fernandes Jr., A., Candies, J.M., Cardoso, K.F., Araujo Jr., J.P., 2008. PCR detection of staphylococcal enterotoxigenes in Staphylococcus aureus strains isolated from raw and pasteurized milk Vet. Microbiol. 132, 408-413.

Rossetti, C.A., 1993. Prevalence of subclinical mastitis caused by S. aureus in the Buenos Aires dairy area and its susceptibility to antibiotics Vet. Argentina. 10, 323-326.

Sagdic, O., Tuluoglu, D.D., Ozcelik, S., Simsek, B., 2002. The chemical and microbiological quality of ice-cream consumed in Isparata market Ziraat. Fakultesi-Dergisi,Ataturk Uni. 33, 441-446.

Said, M.R., Fahmy, M.A., 1991. A survey of incidence of some S. aureus, E. coli and B. cereus in some types of Egyptian cheeses in Assiut city J. Assiut Agric. Sci. 22, 239-246.

Shalaby, M.I. 2012. Detection of Staphylococcus aureus enterotoxin genes in strains isolated from milk in cattle with reference to its antibiogramM.V.Sc. Thesis, Zag. Univ., Egypt.

Stewart, C.M., Cole, M.B., Schaffner, D.W., 2005. Managing the Risk of Staphylococcal Food Poisoning from Cream-Filled Baked Goods to Meet a Food Safety Objective. Journal of Food Protection 66.

Sudershan, K., Ashwani, K., 1996. Occurrence of some bacterial pathogens of public health significance in bovine raw milk. Haryana veterinarian. Dairy Sci. Abst. 6.

Tondo, E.C., Guimaraes, M.C., Henriques, J.A., Ayub, M.H., 2000. Assessing and analyzing contamination of dairy products processing plant by S. aureus using antibiotic resistance PFGE Candian J. Microbiol. 46, 1108-1114.

Wafy, Y.M. 2006. Sanitary improvement of serving milk and dairy products in Assiut University Hospitals Ph.D. Thesis, Assiut Univ., Egypt.

Zschock, M., Kloppert, B., Wolter, W., Hamann, H.P., Lammler, C.H., 2005. Pattern of enterotoxin genes seg, seh, sei and sej positive S. aureus isolated from bovine mastitis. Vet. Microbiol. 108. 